\title{
SPORT SPONSORSHIP EFFECTIVENESS - POLISH VOLLEYBALL CASE STUDY
}

\author{
Sebastian, Kot $^{1}$ and Michał, Kucharski ${ }^{2}$ \\ Czestochowa University of Technology, Poland, sebacat@zim.pcz.czest.pl \\ Academy of Physical Education in Katowice, Poland, m.kucharski@awf.katowice.pl
}

\begin{abstract}
While reflecting on sport sponsorship, it is crucial to consider that it is an investment in promotion from the sponsor's perspective. The idea of each investment, including that in sport sponsorship, is to commit money or capital with an expectation of profitable future returns or benefits. Thus, it is essential to undertake actions that enabling sponsors to establish whether a given sponsoring campaign was effective, i.e. whether it generated more benefits than expenses. This article presents the possibility of using Advertising Value Equivalency (AVE) to evaluate sport sponsorship effectiveness. Research conducted among Polish volleyball clubs aimed at recognizing factors considered by sponsors while evaluating results of engaging in sport sponsorship. The results and conclusions are presented in the content of the article. Additionally, there were introduced levels of AVE obtained by the most frequently displayed sponsors' branches of Plus Liga Kobiet and clubs participating in it in the seasons of 2008/2009, 2009/2010, and 2010/2011..
\end{abstract}

KEY WORDS: advertising value equivalency, sport sponsorship

\section{INTRODUCTION}

The starting point for considerations presented in this article is an assumption that company carrying out planned marketing activities should be aware of results obtained by the action. It allows an evaluation of the appropriateness of using enterprise resources in connection with strategy adopted to reach and interact in target markets. It is possible to observe different marketing strategies used by enterprises, which differ in time horizon, objectives, size and type of the expenditure, used tools etc. [6] Another element that differentiates marketing strategies, is the use of sport sponsorship in view of company promotional activity. Companies that possess well-established, well-known brand in the market in which they operate for a long time, decided to use sponsorship more often and on larger scale $[5,8]$.

\section{ADVERTISING VALUE EQUIVLENCY AND MEASUREMENT OF SPONSORSHIP EFFECTIVENESS}

In literature it is possible to come across depiction of sponsorship as a separate tool of promotion-mix (classification of sales promotion tools by Grabarski, Rutkowski, Wrzosek) [9] or with assignation of it to activities associated with Public Relations [11]. But everybody agreed to treat it as an element of marketing activities. Considering that sponsorship activities are associated with the fact that company incurs expenditure, which may take a form of providing funds, property or services [1], it should also bring tangible results [4, 7]. It is consistent with a diagram of relationship between inputs and effect, which is as follows: Capital $\rightarrow$ Resources / Skills $\rightarrow$ Actions $\rightarrow$ Effects [10]. Effects of marketing activity can be considered in narrower and wider approach. In a narrower approach, effect of marketing activities is seen as an advantage, which company achieved through the use of marketing. In this approach, an effect can be understood as for example increase in sales volume, but not profit, as this can be determined only by taking into account expenses incurred for marketing activities, and these, in turn, are not taken into account in narrower approach. In wider approach effects are compared with expenses incurred to obtain it. In this way, comparing effects of marketing activities together with their costs (expenditures), it is possible to determine their effectiveness [2, 3].

The fact that in literature, much more attention is given to the use of sports sponsorship than its effects, has become a motive for measurements, which aim was to diagnose factors, which are significant for sponsoring companies while evaluating results of engaging in sport sponsorship. Twenty volleyball clubs, which were in competition in Plus Liga and Plus Liga Kobiet in the season 2011/2012, were examined. These club budgets, for one season, amount from a few to several million PLN. Sponsors contribution amounts more that $60 \%$, which means that they are the most important link in financing volleyball clubs participation in professional games. The number of sponsors in each of clubs ranges from several to tens. It can reveal that from the perspective of sports clubs cooperation with one, and often with several companies, is insufficient to collect an adequate budget. In addition, assuming that it is harder to find a new sponsor than to maintain the current one, the person responsible for the cooperation with sponsors of sports clubs should know what sponsors expect and try to do everything to fulfill these expectations. 17 from 20 clubs decided to take part in the survey. In their replies, 12 of them indicated following factors taking into account by their sponsors while evaluating results of engaging in sport sponsorship Table 1.

Representatives of volleyball clubs indicated 20 different factors taken into account by their sponsors while evaluating results of engaging in sport sponsorship. Among them, only three make it possible to determine the effectiveness of the sponsorship campaign in accordance with the concept of a wider approach to the effects of marketing activities. These are: obtained media value, return on investment and increased interest in services and products of sponsors.

These factors, compared with the costs incurred by companies for sponsorship present effectiveness of sponsor activities. 
Table 1. Factors taking into account by sponsors of Polish volleyball clubs while evaluating results of engaging in sport sponsorship

Factors which are important for sponsors of Polish volleyball clubs while evaluating results of engaging in sport sponsorship

Obtained media value (7) (Visibility of advertisement)

The image of the sponsored club (6)

\section{Clubs that indicated a} particular factor as an important for their sponsors while evaluating results of engaging in sport sponsorship Budowlani Łódź, Impel Gwardia Wrocław, KS Pałac Bydgoszcz, AZS Politechnika Warszawska, Fart Kielce, Indykpol AZS Olsztyn, ZAKSA Kędzierzyn-Koźle

Bank BPS Muszynianka Fakro Muszyna, KS Pałac Bydgoszcz, PTPS Piła, Indykpol AZS Olsztyn, PGE Skra Bełchatów, ZAKSA Kędzierzyn-Koźle

Budowlani Łódź, PTPS Piła, AZS Politechnika Warszawska, Sport results (6) Fart Kielce, Indykpol AZS Olsztyn, Tytan AZS Częstochowa

Bank BPS Muszynianka Fakro Muszyna, KS Pałac Bydgoszcz,

Television transmission of matches (5)

Fart Kielce, Indykpol AZS

Olsztyn, Tytan AZS Częstochowa

Professional service in the implementation of the sponsorship agreement (4)

Bank BPS Muszynianka Fakro Muszyna, KS Pałac Bydgoszcz, Delecta Bydgoszcz, Indykpol AZS Olsztyn

KS Pałac Bydgoszcz, AZS

Number of fans in sports facilities (3)

Politechnika Warszawska, Fart Kielce

Number of fans in front of TV (3)

Bank BPS Muszynianka Fakro Muszyna, KS Pałac Bydgoszcz, Indykpol AZS Olsztyn

Delecta Bydgoszcz, Fart

Interpersonal relationships, including business (3)

Ability to implement corporate social responsibility Kielce, PGE Skra Bełchatów

KS Pałac Bydgoszcz, PGE Skra Bełchatów

\begin{tabular}{|c|c|}
\hline $\begin{array}{c}\text { Advertisement on printing } \\
\text { materials (1) }\end{array}$ & Impel Gwardia Wrocław \\
\hline $\begin{array}{c}\text { Advertisement on the Internet } \\
(1)\end{array}$ & Impel Gwardia Wrocław \\
\hline Realization of sports show (1) & PTPS Piła \\
\hline $\begin{array}{c}\text { Financial transparency of the } \\
\text { club (1) }\end{array}$ & PTPS Piła \\
\hline Return on investment (1) & Delecta Bydgoszcz \\
\hline $\begin{array}{c}\text { Amount of information about } \\
\text { the club in local media (1) } \\
\text { and products of sponsors (1) }\end{array}$ & Indykpol AZS Olsztyn \\
\hline $\begin{array}{c}\text { Funs reach (1) } \\
\text { Possibility of participation and } \\
\text { promotion of the brand during } \\
\text { the match (1) }\end{array}$ & PGE Skra Bełchatów \\
\hline $\begin{array}{c}\text { Organization of } \\
\text { accompanying events (1) }\end{array}$ & PGE Skra Bełchatów \\
\hline Transfer image (1) & Tytan AZS Częstochowa \\
\hline
\end{tabular}

Source: own work based on survey
Figures from Table 1 reveal that obtained media value, also known as advertising value equivalency is the most frequently mentioned effect taken into account by sponsors. In addition, respondent's answers on one of the next question contained in questionnaire present importance of advertising value equivalency for a sponsor. They were asked to indicate how important to their sponsors are factors listed by researchers that may be taken into account while evaluating results of engaging in sport sponsorship. Each factor could be evaluated as very important, important, neutral, unimportant and insignificant. Among listed items appeared a media value, which according to respondents is an important factor for their sponsors while evaluating results of engaging in sport sponsorship.

Advertising value equivalency may be understood as an amount of money that should be spend on traditional forms of advertising to get the same level of exposure of company logo/brand as the level of exposure achieved through engaging in sport sponsorship. Sponsors, due to cooperation with sports entity, have guaranteed by sponsoring agreement benefits, such as exposure of sponsor's logo on various media available to sports entity or sportsperson. When calculating the advertising value equivalency generated by television transmission of sports events, it must be determined how many times sponsor's logo appeared in full in specified size (calculated as a percentage of the size of the screen) for the time specified in advance. Then the length of particular logo exposures, which fulfill a certain criteria is totalized. Obtained time is compared with the price of television advertising established in price lists of a particular stations for air time, when transmission of the sport event was presented. The situation presents similarly in case of photos and articles appearing in press and on the Internet, with the difference that in this case attention is put on surface of sponsor's logo exposure.

All potential sources of media value can be analyzed, and after adding results, it is possible to answer the question about the level of advertising value equivalency received by a particular brand. In addition, it is possible to determine an approximate marketing value of the club by adding advertising value equivalency results obtained by all sponsors engaged in cooperation with the club. Then the value of the league is determined by adding media values of all clubs participating in competition to the league. It is presented on Figure 1 and concerns a value of female top division in indoor volleyball in Poland.

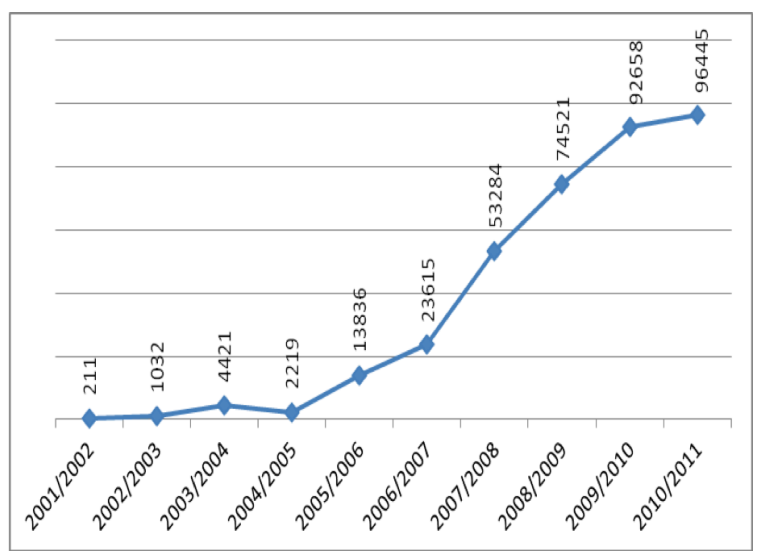

Figure 1. Change in media value of Polish women volleyball league in seasons from 2001/2002 to 2010/2011 (in thousand PLN)

Source: own work based on PLPS data from particular seasons

Presented data show that media value of all league may change over years. It is mostly dependent on the fans' interest. Media 
interest should change in the wake of change of fans' interest in particular games. Increased number of potential television viewers during the transmission of particular sport discipline encourages broadcasters to purchase broadcasting rights for the discipline. Other media, including newspapers and the Internet, are also willing to allocate more space to present events of the discipline, bank on greater interest of advertisers and readers. This in turn makes sponsors to support team of the league. They turn up in media more often, thanks to their advertising value equivalency increases, increasing the value of the entire league. This simplified model to generate a media value shows that starting point to presented increase in league value is fans' interest. It is shown on Chart 1.

According to rules for determining the effectiveness of actions taken, and assuming that the advertising value equivalency is the effect of sponsorship, each sponsor can determine the level of effectiveness of their engage in female volleyball. It is enough to know the amount of expenditures incurred for sponsoring the club or league, because dividing obtained level of advertising value equivalent by costs incurred, it is possible to obtain information about sponsorship effectiveness. Advertising value equivalency shows how often television viewer, reader, or web surfer can come into contact with the sponsor's logo or name. However, it does not show how often one saw sponsor's brand and how it affected his attitude towards it. Advantages of advertising value equivalency include the possibility of its use for the comparison of results obtained by sponsors' brands by the same or different clubs in the same or different disciplines. In this way companies can determine, which discipline or club is the best to be sponsored to get the best results due to engagement in cooperation with particular sport entity.

\section{SUMMARY}

From presented considerations follow that advertising value equivalency may be used in research on the sport sponsorship effectiveness, but sponsors evaluation of their engagement in sport sponsorship should not base on it, as it is in case of sponsors of Polish volleyball clubs. Methods allowing to determine measurable benefits obtained by company through individual campaigns should be used while evaluating the effectiveness of sports sponsorship and other marketing activities. It requires additional expenditures to conduct market research or to outsource it external research agencies. However, these costs can return repeatedly, in case when conducted promotional activities using sport sponsorship are ineffective. Then, company finishing his cooperation with sport entity does not incur further costs associated with its financing or by reorganization of sponsorship strategy increase its efficiency.

\section{REFERENCES:}

1. Araźny D., Sponsoring sportowy - forma promocji przedsiębiorstwa, /in:/ Mruk H., Jardanowski P., Matecki P., Kropielnicki K. (red.), Marketingowo o sporcie. Wyd. Sport \& Business Foundation, 2005.

2. Baran R., Miary stosowane przy ocenie efektów działań marketingowych, Marketing i Rynek, 1/2008.

3. Baran R., Pomiar efektów marketingu, Marketing i Rynek, $8 / 2006$.

4. Brzeziński S., Czynniki kształtujące orientację rynkowej odpowiedzialności społecznej, Marketing i Rynek 11/2012

5. Grabara J., Okwiet., Advertising in Small and Medium Enterprises - the Practical Examples and Advices. Annales Universitatis Apulensis. Series Oeconomica Nr 13 Iss.2, 2011

6. Grabara J., "Employer's Expectations Towards the Employees from the Marketing and Management Department." Polish Journal of Management Studies Vol. 7, 2013

7. Herbuś A., Ślusarczyk B. The Use of Corporate Social Responsibility Idea in Business Management. Polish Journal of Management Studies. Vol. 6, 2012

8. Jensen J. A., Hsu A., Does sponsorship pay off? An examination of the relationship between investment in sponsorship and business performance, International Journal of Sports Marketing \& Sponsorship, 2/2011.

9. Wiktor J. W., Promocja - system komunikacji przedsiębiorstwa $\mathrm{z}$ rynkiem, Wydawnictwo Naukowe PWN, 2006.

10. Wrzosek W., Wokół efektów marketingu, Marketing i Rynek, 5/2006.

11. Żbikowska A., Public relations, Wyd. PWE, 2005. 